\title{
Impact of demographic and loan size on the probabilities of women freedom of movement empowerment
}

\author{
Kausar Yasmeen \\ Candidate of $\mathrm{PhD}$, School of Economics, Banking and Finance \\ UUM College of Business (COB), Universiti Utara Malaysia, 06010 Sintok, Kedah, Malaysia \\ E-mail: eco.yasmeen@gmail.com \\ Prof. Dr Mohd Zaini Abd Karim \\ Othman Yeop Abdullah Graduate School of Business \\ Universiti Utara Malaysia, 06010 Sintok, Kedah, Malaysia \\ E-mail: zaini500@uum.edu.my
}

Accepted: October 11, 2014

Doi:10.5296/ ijafr.v4i2.6659 URL: http://dx.doi.org/10.5296/ ijafr.v4i2.6659

\begin{abstract}
The purpose of this paper is to evaluate the impact of microfinance involvement of women's freedom of movement empowerment. The cross sectional data for this study is collected by using questionnaires. Using random sampling, 744 households are selected from female clients of Khushhali Bank and National Rural Support Program from three districts namely district Bahawalpur, District Bahawalnagar and district Rahim Yar Kan of Division Bahawalpur, Pakistan. We used the multinomial logit model. The loan size increases women's freedom of movement empowerment. This paper is intended to be a valuable contribution in term of socio- economic and political arena. This paper recommends that the future research should be done in other province of Pakistan, as there is cultural difference between Punjab, Sarhad and Baluchistan. In addition, the future research can examine the impact of socio cultural factors.
\end{abstract}

Keywords: Microfinance, women's freedom of movement, probabilities, Pakistan 


\section{Introduction}

Females living in developed countries contribute to their national income more than women living in underdeveloped and developing countries. The economic development of the country depends on both working male and female. In the developed countries, women have decision making empowerment. To improve the economic power of public and economic development of under developing countries like Pakistan, developed countries provide loans through different programs through IMF and World Bank. The Pakistani government to secure loans from IMF and World Bank and spend this money on different projects for the well-being of the nation. When government starts projects, it needs machinery and human capitals to implement the project gives hence provide employment to people. However, women living in rural areas of Pakistan are still facing problems of social barriers, freedom in decision making etc. Relative to most countries globally, Pakistan has male dominant society, especially in the rural areas. Usually man are decision maker and women are follower. Women faced many cultural and social barriers to enter in her right of decision making if she is independent, to be independent women need to involve herself in economic activities. Lack of the finance is the major issues that discourage women to involve in economic activities. Women in urban areas have relatively easy access to informal sources of credit like money lender, friends and relatives more than females living in rural areas but, they are charging high rate of interests (TLO, 1998). When the government of Pakistan starts projects involving public through providing them an income in return for their services, the public involved in government projects are mostly male. If the female are supported to get employment in government projects, the living condition of their household can be better because usually female contribute their income to the household. Noreen (2011) found that households in rural areas of Pakistan live at subsistence level; if females are allowed to work, they can contribute their income to households, but females in the rural areas of Pakistan are the most neglected part of the population at the formal and informal level. The problem of poverty cannot be resolved without money, as money generates money or service generates money. Now, women are being supported globally. Various programs serve women by providing them with financing. Microfinance is one kind of financial service that targets especially women. Microfinance involves women in micro business and other income generating activities to empower them. The government of Pakistan provides loans through microfinance institutions to women to resolve the problem of poverty.

According to the Official Report on Strategic Framework for Sustainable Microfinance in Pakistan (2011), there is interest on the Pakistani government and state bank of Pakistan to promote women's empowerment in Pakistan. This report highlights the importance of microfinance institutions in Pakistan. Since 2000, Pakistan has supported microfinance institutions to empower women. In Pakistan, microfinance sector is underdeveloped and is relatively young. Pakistan entered late in the microfinance industry, but made considerable achievement and progress in this field. Both State Bank of Pakistan and Government of Pakistan is fully committed to achieve the growth and development of the Pakistan through microfinance on the basis of sustainability. Government of Pakistan is helping the women through introducing microfinance banks under the microfinance institutions ordinance 2001. 
At present, the microfinance sectors of Pakistan are globally recognized for well-developed legal, regulatory, and strategic framework. Notwithstanding these significant attainments, the micro-credit growth target of reaching out to 3 million borrowers by the end of 2010, set out in the strategy, remained unattained for a variety of causes. So, State Bank of Pakistan has introduced 10 microfinance operations through additional prudential regulations. Pakistan has entered into a new phase of microfinance development. The government supports NGO's through Rural Support Programmes by sponsoring a number of foundations such as modeled along Kashaf Foundation and the Grameen Bank of Bangladesh. Approximately forty microfinance institutions operate in Pakistan, out of which, 19 institutions are members of Pakistan the microfinance network. National Rural Support Program (NRSP) which was developed in 1990 plays a major role in the development of microfinance and representing the highest numbers of MFIs in Pakistan. NRSP become one of the best and largest lending microfinance institutions in Pakistan. According to its official report, out of the ten Microfinance Banks, those have been established by State Bank of Pakistan. NRSP and Khushhali Bank are the two key banks that are working efficiently.

Shortly, on the basis of the above discussions we could argue that both the State Bank and government of Pakistan are continuously trying to increase loan facilities for women to help them empowering them economically. As most of the Pakistani women are poor, it is supposed that microfinance leads them to income generating activities that empower them and this empowerment boost up their empowerment.

Though, it is important to carefully evaluate whether microfinance scheme has a positive impact on poor females. In this connection, several researchers have studied the overall impact of microfinance on women empowerment. The results are mixed. Several studies show that, microfinance has a positive impact on women's empowerment while some studies show that microfinance has no impact on the women's empowerment. Banuet al. (2000) found positive impact of microfinance on empowerment, while Asim (2008) found a negative impact of microfinance on women empowerment in Pakistan. The empirical findings can be different by applying In addition, there is lack of studies that indicate the level of impact of microfinance on women's freedom of movement empowerment.

However, this study contributes methodologically by applying the multinomial logit model. The findings show level of impact of microfinance on women's freedom of movement empowerment. In addition, these studies help the researcher, edit literature, contributes socially, economically and helps the policy makers.

\section{Literature Review}

Some studies (Hasherniet al. 1996, Parveen, 2007) have highlighted that accessibility to loan through the poor has a big positive impact on empowerment, quality of life and living standard. Rehman and Khan (2007), attempted to explore how microfinance helps poor people to improve their living standard. They concluded that provision of microfinance in the form of collateral free loans, is an effective mechanism for reduction of poverty, improving health, education, legal rights, sanitation and happiness. Chaudary and Nosheen (2009) narrate that micro credit has a significant impact on women empowerment. Nevertheless, on 


\section{MInstitute Mach $^{m}$}

International Journal of Accounting and Financial Reporting ISSN 2162-3082 2014, Vol. 4, No. 2

the basis of the previous studies, limited evidences exist on which type of empowerment is more significant for poor female. The above previous studies show the positive impact of microfinance empowerment. However, some studies also show that microfinance has no impact on women's empowerment. Chowdhury (2008) found that in Pakistan, poverty is not declining through micro-finance, as poor households simply remain poor because of the extra burden of interest rate and debt. Microfinance institutions charge high rate of interest, where this interest rate has an inverse relationship with empowerment. Asim (2008) found that microfinance has no positive impact on female empowerment.

There are several studies that show the importance of different variables thteffect on women empowerment. In case of age, Mason (1986) argued that women's behavior differs across the stages in the life cycle. It is also supported by Noreen 2010, Handy \&Kassam 2004, and Mustafa et al. 2008. Malhotraet al. (2002) states that education has been pointed out as a key indicator of empowerment through several literature. Family size is also an important variable affecting to empowerment. Hasherniet al. (1996), Parveen (2007), Hashemiet al. (1996), Banuet al. (2000), Becchetti (2009), and Bandyopadhyayet al. (2011), use family size to study the impact of micro finance on women's empowerment because number of household members affect women's empowerment. Marital status is also important because life partner interferes in the wife's matter, especially in poor and developing countries.Hasherniet al. (1996), Parveen (2007), Hashemiet al. (1996), Banuet al. (2000),Becchetti (2009), and Bandyopadhyayet al, (2011) include marital status to study the impact of microfinance on women empowerment. It is supposed that if the female is married, she feels confident and believes her life partner helps her in good and bad circumstances related to her empowerment.

This study conclude the above literature and finds that there are mixed results, Hasherni et al. (1996), Parveen (2007) and Banuet al. (2000) found positive impact of microfinance on empowerment, while Asim (2008) found a negative impact of microfinance on women empowerment in Pakistan. In addition, It is important to carefully evaluate whether microfinance have a positive impact on poor female. The literature review indicates that those females who have, better social position of natal family, sons, higher income, and the capacity to pay dowry during their wedding are more likely to have a higher social position. Some microfinance providing institute like NRSP and Khushali Bank are struggling to help the poor women in Pakistan. There are busy in enhancing women in business, but it is not certain whether these bank's micro-credit programs have improved the women economic decision making empowerment.

Nevertheless, the theory of human capital theory (1960) said, education is a key channel to improve the productive quality of labor. Investment in human capital can take place through training and education. Education is a very important factor to reduce poverty and to empower women. According to human capital theory, it can be supposed that if an educated women borrow microfinance, its supposed might be more productive and able to contribute more to the household. Hence, there is no study that this study that attempts to include the interaction term between microfinance and education and interaction term between loan size and education as one of the independent variable. 


\section{Status of women in Pakistan}

Roomi and Parrott (2008) mention the status of women in Pakistan as a major barrier for the development of female entrepreneurs. They identified a lack of access for women to capital, land, business premises, information technology, training, and agency assistance in addition to missing encouragement by male family members in a patriarchal society, limited spatial mobility, and a dearth of social capital in Pakistan. Hausmann, Tyson, and Zahidi (2008) rank Pakistan on the 134th position out of 135 countries with respect to gender gap. Pakistan's economy is based on agriculture and $51 \%$ of women live in rural areas (Muhammad, Shaheen, Naqvi, \&Zehra, 2012) working on household farms or within the household (Sathar\&Kazi, 2000). Though officially women have the right to own land, it is mostly inherited by male children and thus the access to land for women is often restricted (Agarwal,1994). The labor force participation of women in Pakistan in 2012 was 24\% (World Bank, 2014), putting the country on rank 172 out of 183 globally. According to the Economic Survey of Pakistan 2012-2013 (Ministry of Finance of the Government of Pakistan, 2013) the overall rural female literacy rate is $35 \%$ with a male literacy rate of $64 \%$. Rural literacy is also lower than the average female literacy in Pakistan (47\%). Still, class influences access to education and employment in rural settings. The combination of a generally low accessibility to health care and gender inequality leads to a low access to health care for women (Society of Obstetricians \& Gynaecologists of Pakistan, 2009) resulting in a relatively high female mortality rate. Furthermore, active participation of rural women in Pakistan is hindered due to limited participation in the workforce, immobility, domestic pressure, income disparity, and the lack of decision-making opportunities (ShabibulHasan, 2012). Hence, studies suggest that women's mobility is limited in Pakistan. Mumtaz and Salway (2005), for instance found that only $18 \%$ of their interviewees have travelled alone during four weeks before being interviewed. A further indicator of the status of women in Pakistan is violence against women, an enormous problem in South Asian countries and in Pakistan (Niaz, 2003).

\section{Policies regarding women empowerment in Pakistan}

The Pakistani government follows the millennium development goals. With regard to women empowerment policies with respect to education are important. Consequently, government policies strive to ensure that by 2015 all children, independent of gender, will be able to complete primary schooling. Secondly, the National Education Policy plans to eliminate gender disparity in education at all levels until 2015 (Ministry of Finance of the Government of Pakistan, 2013) and therefore established a ministry for education and training. Other policies to strengthen women and empowerment are an initiative to provide state land to landless women (The Daily Times, 2012), an income support program that combines financial products such as microfinance, insurance and grants (see http://www.bisp.gov.pk/), training of women in rural jobs, and assisting them in marketing their products. Microfinance and women empowerment in Pakistan were first promoted in the 1990s and is regulated by the State Bank of Pakistan. In 2012-13 the microfinance platform mix market counted 28 microfinance institutions in Pakistan. As of October 2013 they served 2.7 million borrowers with a total loan sum of $\$ 483$ million (www.mixmarket.org). The biggest microfinance institutions in Pakistan with loan portfolios higher than $\$ 35$ million are Kushhali Bank, 


\section{I Macrothink}

International Journal of Accounting and Financial Reporting ISSN 2162-3082

TMFB, NRSP, FMFB Pakistan and Kashf Foundation. The average percentage of female borrowers in the loan portfolios of Pakistani microfinance institutions in 2012-13 was 63\%. At least eight of the Pakistani microfinance institutions only lend to women. According to mixmarket.org, the biggest among them is Khushali Bank and Kashaf foundation.

\section{Data Collection Strategies}

The cross sectional data for this study was collected by using questionnaire. Data on women empowerment was collected from two types of women: first the women who were not involved in microfinance, and second the women who were clients of Khushhali Bank and National Rural Support Programme. Most of the questions which were used in the questionnaire were from Pitt, Khandker and Cartwright (2006) study. Hence, 744 women were selected as sample. The data is collected from three districts namely District Baawalpur, District Bhawalnugar and district Rahim YarKanof Division Bahawalpur. A stratified random sample of 744 household were drawn from population, approximately 372 questionnaires were filled through female clients of Khushhali Bank and National Rural Support Programme while 372 questionnaires were filled through those women who are not involved in microfinance.

\section{Models for Women's freedom of movement empowerment}

$$
\begin{aligned}
& Y_{1}=\beta_{0}+\underline{\beta}_{1} \text {Age }_{i}+\beta_{2} \text { edu }_{i}+\beta_{3} \text {Fsize }_{i}+\beta_{4} \text { Annual } I_{i}+\beta_{5} M_{i}+\beta_{6} \text { Loan Size }_{i}+\beta_{7}(L S \\
& * \text { edu) })_{i}+\text { ei }
\end{aligned}
$$

As women's freedom of movement empowerment (Y1) is qualitative variables, we used the multinomial Logit model to estimate the impact of microfinance on women's empowerment. In the light of model, to analyze the impact of microfinance on woman's empowerment, we included age, education, annual income, loan size, and marital status as independent variables. The dependent variable women's freedom of movement empowermentis measured in 3 catagories " 0 ", "1" and 2. Age, education (edu), annual income (Annual I) was measured in numeric values (numbers) while marital status(MS) and loan size was measured in dummy variables. 0 shows to unmarried women and to women who are not involve in microfinance and 1 shows to married women an women's who are involvement in microfinance.However, the conceptual model of this study is presented in figure 1.1.

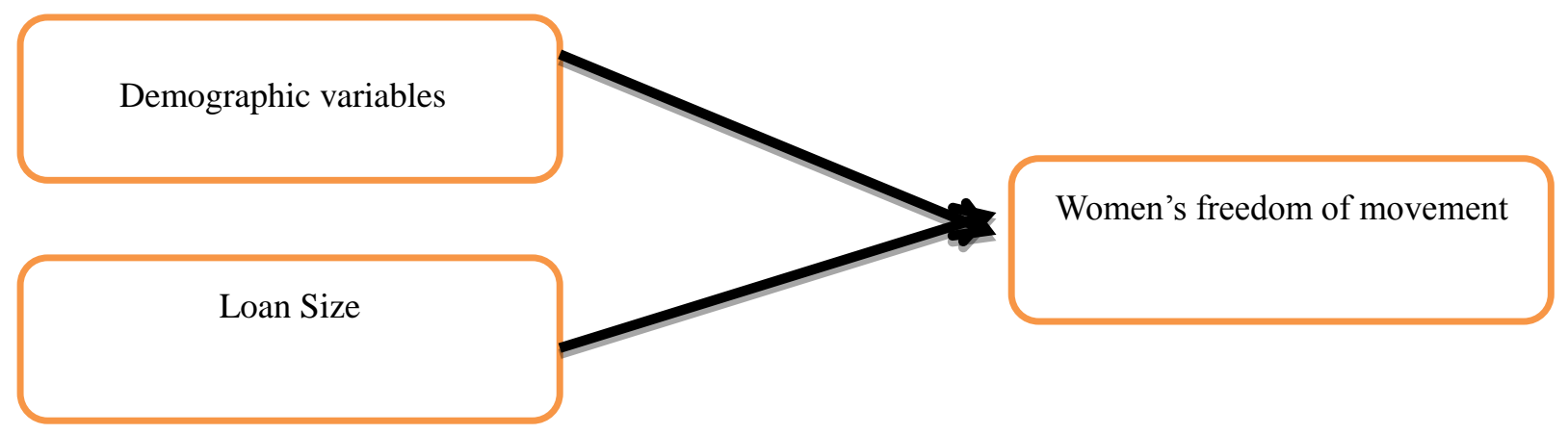

Figure 1.1 conceptual model of the study 


\section{Impact of explanatory variables on women freedom of movement empowerment}

If I move to the sometime ability and full freedom relative to no freedom condition here is the variable age and education has insignificant relation with the women empowerment in freedom of movement. In sometimes freedom and full freedom compare to no freedom education is insignificant but positively related with women empowerment in freedom of movement. According to our descriptive analysis $87.4 \%$ respondents in our sample were illiterate, 4.3 only had primary education, 8.3 had matriculation while no of respondents in secondary education graduation and masters was zero., Might be that's why our this variable is insignificance but have positive relation. However we can say in this case of Punjab poor women education and age is not a predictor of women empowerment in freedom of movement. Nessa.T (2011) also found the same result about impact of education on women freedom of movement, Asim (2009) found the age insignificant in freedom of movement.

Table 1.1 Results/Parameter Estimates (Multinomial logit)

\begin{tabular}{|c|c|c|c|c|c|c|}
\hline \multirow[t]{2}{*}{ Y1 } & \multicolumn{3}{|c|}{ Sometime ability relive to No freedom } & \multicolumn{3}{|c|}{ Full freedom relive to no freedom } \\
\hline & Coef. & $\mathrm{p}$ & Std. Err. & Coef. & $\mathrm{p}$ & Std. Err. \\
\hline Age & -.0069826 & 0.630 & .0144836 & -.0138327 & 0.301 & 013369 \\
\hline Education & .0450718 & 0.515 & .06919 & .1013478 & 0.124 & .065805 \\
\hline Income & .00001468 & 0.081 & .356 & .000021 & 0.007 & .116 \\
\hline Marital status & -1.064221 & 0.250 & .9242904 & -2.641953 & 0.000 & .6797148 \\
\hline Loan Size & 9.256 & 0.800 & .0000366 & .0000685 & 0.043 & .0000339 \\
\hline _cons & .0236075 & 0.978 & .8720745 & .0753736 & 0.926 & .8079198 \\
\hline
\end{tabular}

1 (sometime ability) (base outcome)

Note:*****and andicate that variables are significant at $1 \%, 5 \%$ and $10 \%$ level of significance respectively. Sometimes freedom is the a base outcomes.

Table 1.1 Results/ Parameter Estimates (Multinomial logit)

The variable income variable has positive and significant at 10 percent in sometimes freedom and 5 percent significant in full freedom compare to no freedom, As income increase the women empowerment in freedom of movement will increase. Women's income has positive relation with her freedom of movement ability because working women have strong influence of her personality in the family and can be dominant in the family. That's why the trend of the society in Pakistan going change and every one want working women as his life partner just because not of the reason that she will brought up her kids well but it is the need of the every family to increase their family income. Better life is only possible if both members are working hand (wife and husband). If the women is earning her decision can be consider, in general observation in Pakistani society working women who earn money even in her family she has power full status compare than a family member who is not earning. Parents also try to give them good education that will be result in good earning they suppose if their daughter will earn she can find good suitor/ husband. So, when women earn than they can part of decision. According to the previous studies, Parveen, 2007, Noreen 2009 and Tuseef 2011, use annual income to check the impact of micro finance on women empowerment. In 
some time ability compare to no freedom marital status is insignificant while in full freedom marital status is significant at 1 percent but negatively correlated with freedom of movement. Marital status is significant in full freedom compare to no freedom but have negative relationship with the freedom of movement, in sometimes freedom compare to no freedom the result is insignificant because in Pakistan the girls are not educated as our descriptive analysis show, when a women is free at home parents fix her marriage soon. In Pakistan girls get married in early age. In our sample we have unmarried women only $3.2 \%$ out of 100 percent. In sometime ability compare to no freedom, The variable loan size has positive and insignificant relation with women empowerment. In full freedom relative to no freedom the variable loan size is significant at 1 percent and positively related with the empowerment of women's decision. In full freedom it is supposed if a women borrow the earn and their decisions are considers. So we would reject the null hypothesis. result of our study is similar with the results of Parveen, 2007, Hashemiet al. 1996, Banuet al. (2000), Becchetti 2009, and Bandyopadhyayet al. 2011, found that loan size has positive impact on women's empowerment.

\section{Impact of change in the explanatory variable on women freedom of movement empowerment}

According Richard Williams (2012) we get marginal effects of the component terms. The value of the interaction term can't change independently of the values of the component terms, so we can't estimate a separate effect for the interaction". The estimated coefficients in the multinomial logit model are of limited use because they cannot be used to infer the direction of the marginal effect of each explanatory variable, the marginal effect of a given variable on the probability of choosing any type of ability of freedom of movement (no freedom, sometimes freedom and full freedom) is a function of all of the estimated.

Table 1.2 Marginal Effect of the MNLM

\begin{tabular}{|c|c|c|c|}
\hline Variable & No freedom & Sometimes freedom & Full freedom \\
\hline Age & $\begin{array}{c}.0007079 \\
(0.252)\end{array}$ & $\begin{array}{c}.0002469 \\
(0.887)\end{array}$ & $\begin{array}{c}-.0009549 \\
(0.609)\end{array}$ \\
\hline Education & $\begin{array}{c}-.0038776 \\
(0.202)\end{array}$ & $\begin{array}{c}-.0080142 \\
(0.210)\end{array}$ & $\begin{array}{c}.0118918 \\
(0.085)\end{array}$ \\
\hline Income & $\begin{array}{l}-1.036 \\
(0.000)\end{array}$ & $\begin{array}{c}-1.03 \mathrm{e}-06 \\
(0.087)\end{array}$ & $\begin{array}{c}2.066 \\
(0.002)\end{array}$ \\
\hline Marital S & $\begin{array}{l}.506775 \\
(0.004)\end{array}$ & $\begin{array}{c}-.0004058 \\
(0.997)\end{array}$ & $\begin{array}{c}-.5063692 \\
(0.001)\end{array}$ \\
\hline Loan Size & $\begin{array}{c}-2.12 * * * \\
(0.000)\end{array}$ & $\begin{array}{l}-9.666 \\
(0.013)\end{array}$ & $\begin{array}{c}.0000118 \\
(0.005)\end{array}$ \\
\hline
\end{tabular}

Note. The figures in parenthesis are p-values; ${ }^{8 * 8},{ }^{* 8}$ and ${ }^{*}$ denote that the corresponding coefficient is significant at the $1 \%, 5 \%$ and $10 \%$ level, respectively. Mfi

refers to the microfinance involvement. No freedom is the base outcome.

Hence, we proceed by calculating the marginal effect of each explanatory variable on the probability of choosing each type ability of freedom of movement. As documented in Table 
1.2 we find the following results.

First, the marginal effect of respondent's age on the probability of choosing ability of freedom of movement is insignificant for all, (no freedom, sometimes freedom and full freedom) but have positive relation with all choices (no freedom, sometimes freedom and full freedom)

Second, the marginal effect of respondents' education on the probability of choosing ability of freedom of movement is significant for full freedom only. In particular, if the education of a respondent increases by one year, the probability of choosing full freedom is expected to rise by .0118918. These results indicate that full freedom of freedom of movement appears to cater to educated people while no freedom and some time ability seem to be indifferent towards the education of respondent.

Third, the marginal effect of annual income of respondent on the probability of choosing full freedom is significant. In particular, if the number of annual income of respondent increases by PKR, 1000 from its mean value of income, the probability of choosing full freedom is expected to rise by 2.066 , the probability of choosing sometime ability and no freedom is significant but negatively related with freedom of movement. No freedom is expected to fall by -1.036 and sometimes freedom will fall by.103.. These results suggest that no freedom and sometimes freedom appear to cater to relatively low income while full freedom to relatively high income.

Fourth, the marginal effect of marital status of respondent on the probability of choosing full freedom is significant. In particular, if the respondent get married, the probability of choosing full freedom is expected to rise by .242 , the probability of choosing sometime ability is insignificant but positively related with freedom of movement. No freedom is expected to fall by-.188. These results suggest that no freedom appear to cater to relatively unmarried while full freedom to relatively married.

Lastly, the marginal effect of respondents' loan size on the probability of choosing ability of freedom of movement is significant for full freedom only. In particular, if the loan size of a respondent increases by PKR: 1000, the probability of choosing full freedom is expected to rise by .0000118 . These results indicate that full freedom of freedom of movement appears to cater to educated people while no freedom and sometime ability seem to be indifferent towards the education of respondent.

\section{Conclusion}

The purpose of this paper is to evaluate the impact of microfinance involvement of women's freedom of movement empowerment. The cross sectional data for this study is collected by using questionnaires. Using random sampling, 744 households are selected from female clients of Khushhali Bank and National Rural Support Programed in from three districts namely District Baawalpur, District Bhawalnugar and district Rahim YarKan of Division Bahawalpur, Pakistan. We used the multinomial logit model.According the finding of this study, the marginal effect of respondent's age on the probability of choosing ability of freedom of movement is insignificant for all, (no freedom, sometimes freedom and full 
freedom). The marginal effect of respondents' education on the probability of choosing ability of freedom of movement is significant for full freedom only. In particular, if the education of a respondent increases by one year, the probability of choosing full freedom is expected to rise by .0118918 . These results indicate that full freedom of freedom of movement appears to cater to educated people while no freedom and some time ability seem to be indifferent towards the education of respondent. The marginal effect of annual income of respondent on the probability of choosing full freedom is significant. The marginal effect of marital status of respondent on the probability of choosing full freedom is significant. In particular, if the respondent get married, the probability of choosing full freedom is expected to rise by .242 , the probability of choosing sometime ability is insignificant but positively related with freedom of movement. No freedom is expected to fall by-.188. These results suggest that no freedom appear to cater to relatively unmarried while full freedom to relatively married. The marginal effect of respondents' loan size on the probability of choosing ability of freedom of movement is significant for full freedom only. In particular, if the loan size of a respondent increases by PKR: 1000, the probability of choosing full freedom is expected to rise by .0000118 . These results indicate that full freedom of freedom of movement appears to cater to educated people while no freedom and sometime ability seem to be indifferent towards the education of respondent. The loan size increases women's freedom of movement empowerment. This paper is intended to be a valuable contribution in term of socio- economic and political arena. This paper recommends that the future research should be done in other province of Pakistan, as there is cultural difference between Punjab, Sarhad and Baluchistan. In addition, the future research can examine the impact of socio cultural factors.

\section{References}

Agarwal, B. (1994). A field of one's own: Gender and land rights in South Asia (Vol. 58). Cambridge, UK: Cambridge University Press.

Ai C, Norton EC (2003) Interaction Term in Logit and Probit Models. Economic Letters 80:123-129. The Stata Journal, 2004, 4(2):103-116.

Ali, I., \&Hatta, Z. A. (2012). Women's empowerment or disempowerment through microfinance: Evidence from Bangladesh. Asian Social Work and Policy Review, 6(2), $111-121$.

Amin, R.; Becker, S.; and Bayes, A. (1998).NGO-Promoted Micro credit Programs and Women's Empowerment in Rural Bangladesh: Quantitative and Qualitative Evidence, The Journal of Developing Areas, Vol. 32, No. 2, pp. 221-36.

Asim, S. A. (2008). Evaluating the Impact of Microcredit on Women's Empowerment in Pakistan, CREB Working Paper No.2- 9, Social Science Research Network.

Banu, D., Farashuddin, F., Hossain A., \&Akter, S. (2000), Empowering women in rural Bangladesh: Impact of BRAC's program.

BartualSanfeliu, C., Cervello’ Royo, R., \&Moya Clemente, I. (2013).Measuring performance 
of social and non-profit Microfinance Institutions (MFIs): An application of multicriterion methodology. Mathematical and Computer Modelling, 57(7-8), 1671-1678. http://

Becerril, J., \&Abdulai, A. (2010). The impact of improved maize varieties on poverty in Mexico: A propensity score-matching approach. World Development, 38(7), 1024-1035,

Bhatt, N., \& Tang, S.-Y. (2001). Delivering microfinance in developing countries: Controversies and policy perspectives. Policy Studies Journal, 29(2), 319-333. http://dx.doi.org/10.1111/j.1541- 0072.2001.tb02095.x.

C1DA (2002). C1DA and Microfinance: A Poverty Reduction Approach Canadian International Development Agency, Policy Branch.

Caliendo, M., \&Kopeinig, S. (2008). Some practical guidance for the implementation of propensity score matching. Journal of Economic Surveys, 22(1), 31-72.

Carolyn, Hannan, (2003). Transforming Empowerment and Gender Mainstreaming, International Symposium on a new Vision for Gender Policy: Equality, Development and Peace. New York April,2003.

Charmes, J., \&Wieringa, S. (2003). Measuring women's empowerment: An assessment of the gender-related development index and the gender empowerment measure. Journal of Human Development, 4(3), 419-435. http://dx.doi.org/10.1080/1464988032000125773.

Chaudary and Nosheen (2009). The Determinants of Women Empowerment in Southern Punjab, Pakistan: An Empirical Analysis, European Journal of Social Sciences, Vol 10-2.pp.101-117

Cheston, S. and Lisa, K. (2002). Empowering women Through Microfinance, Washington: UN IFEM for Micro-credit Summit, 2002.

Chowdhury, S. S., \&Chowdhury, S. A. (2011). Microfinance and women empowerment: A panel data analysis using evidence from rural Bangladesh. International Journal of Economics \& Finance, 3(5), 86-96. http://dx.doi.org/10.5539/ijef.v3n5p86.

Conger, J. A., \&Kanungo, R. N. (1988). The empowerment process: Integrating theory and practice. The Academy of Management Review, 13(3), 471-482.

Cull, R., Demirguec_-Kunt, A., \&Morduch, J. (2007). Financial performance and outreach: a global analysis of leading microbanks. The Economic Journal, 117(517), F107-F133.

De Gobbi, M.S. (2005). Nepal and Pakistan, Microfinance and Micro Development Their Contribution to the Economic Empowerment of Women, SEED Working Paper No. 69 ILO Geneva.

Dehejia, R. H., \&Wahba, S. (2002). Propensity score-matching methods for nonexperimental causal studies. Review of Economics and Statistics, 84(1), 151-161.

Diamond, A., \&Sekhon, J. S. (2012). Genetic matching for estimating causal effects: A general multivariate matching method for achieving balance in observational studies. Review 
of Economics and Statistics,

Duvendack, M., \& Palmer-Jones, R. (2012). High noon for microfinance impact evaluations: Re-investigating the evidence from Bangladesh. Journal of Development Studies, 1-17,

Farooq, O. M. (2009). The challenge of poverty and mapping out solutions: Requisite paradigm shift from a problem-solving and Islamic perspective, Journal of Islamic Economics, Banking and Finance, Volume-5 Number-2, pp.45-76

Fetterman, D. M. (1994).Empowerment evaluation. Evaluation Practice 15(1), 1-15.

Godquin, M. (2004). Microfinance repayment performance in Bangladesh: How to improve the allocation of loans by MFIs. World Development,

Goetz, Anne Marie; and Gupta, RinaSen (1996). Who Takes the Credit? Gender, Power, and Control Over Loan Use in Rural Credit Programs in Bangladesh, World Development, Vol. 24, No. 1, pp. 45-63.

Government of Pakistan, (2004-05) Economic Survey of Pakistan, Islamabad, Ministry of Pakistan.

Haile, H. B., Bock, B., \&Folmer, H. (2012). Microfinance and female empowerment: Do institutions matter?. Women's Studies

Handy, F. and Kassam, M. (2004), Women's empowerment in rural India. Paper presented at the ISTR conference, University of Toronto, Canada, july,2004

Hashemi, S. M., Schuler, S. R., \& Riley, A. (1996). Rural credit programs and women's empowerment in Bangladesh, World Development, Vol. 24, No. 4, pp. 635-653.

Hausmann, R., Tyson, L. D. A., \&Zahidi, S. (2008). The global gender gap report 2008.

Hermes, N., \&Lensink, R. (2011). Microfinance: Its impact, outreach, and sustainability. World Development, 39(6), 875-881. http://dx.doi.org/ 10.1016/j.worlddev.2009.10.021.

Hishigsuren, G. (2007). Evaluating mission drift in microfinance. Evaluation Review, 31(3), 203-260.

Holvoet, N. (2005). The Impact of Microfinance on Decision-Making Agency: Evidence from South India, Development and Change,Blackwell Publishing, Institute of Social Studies vol. 36 (1),pp. 75-102

Hope, R. A. (2007). Evaluating social impacts of watershed development in India.World Development, 35(8), 1436-1449, http://dx.doi.org/ 10.1016/j.worlddev.2007.04.006.

Hoque, M., \&Itohara, Y. (2009). Women empowerment through participation in microcredit program: A Case study from Bangladesh. Journal of Social Science, Vol 5-3, pp 244-250

Human Development Report (1995), United Nations Development Programme, Oxford University Press, New York.

Hunt, J. and Kasynalhan,N.(2002). 'Reflections on microfinance and women's empowerment, 


\section{Ml Macrothink}

International Journal of Accounting and Financial Reporting

ISSN 2162-3082 2014, Vol. 4, No. 2

Development Bulletin, No. 57, pp. 71-75

Hunt, J., \&Kasynathan, N. (2001). Pathways to empowerment?Reflections on microfinance and transformation in gender relations in South Asia. Gender \& Development, 9(1), 42-52.

Iacus, S. M., King, G., \&Porro, G. (2012). Causal inference without balance checking: Coarsened exact matching. Political Analysis, 20(1), 1-24.

ILO (1998).Women in Informal Sector and Their Access to Microfinance, Inter-Parliamentary Union Annual Conference, Windhoek, Namibia, 2-11 April 1998 Indian National Policy for Empowerment of Women. (2001).

Jalan, J., \&Ravallion, M. (2003).Estimating the benefit incidence of an antipoverty program by propensity-score matching. Journal of Business \& Economic Statistics, 21(1), 19-30.

Jejeebhoy, S. J., \&Sathar, Z. A. (2001). Women's autonomy in India and Pakistan: The influence of religion and region. Population and Development Review, 27(4), 687-712.

Journal of Business Management, 6(12), 4514-4521. http://dx.doi.org/ 10.5897/AJBM11.2407.

Kabeer and Naila (2001). Reflections on the Measurement of Women's Empowerment: In Discussing Women's Empowerment-Theory and Practice, Swedish International Development Agency, Stockholm, Sida Studies No. 3. NovumGrafiska AB: S, pp. 17-59

Kabeer, N. (2001). Conflicts over credit: Re-evaluating the empowerment potential of loans to women in rural Bangladesh. World Development, 29(1), 63-84,

Kabeer, N. (2005). Gender equality and women's empowerment: A critical analysis of the third millennium development goal 1. Gender \& Development, 13(1), 13-24.

Kashf Foundation (2011). Annual Report 2009-2010. Lahore: Kashf Foundation.

Kashf Foundation. (2010). Economic gains through the provision of financial services to women in Pakistan (pp. 4). Lahore, Pakistan: Kashf Foundation.

Katchova, A. L. (2010). Agricultural contracts and alternative marketing options: A matching analysis. Journal of Agricultural \& Applied Economics, 42(2), 261-276.

Kavitha,N. (2007). Role of Women IN Microfinance, SSM College of Engineering, Research report, Tamil Nadu, India.

Khan, M. A., Alam, M. F., \& Islam, K. J. (2012). The impact of comanagement on household income and expenditure: An empirical

Khandker, and Shahidur R. (1998). Fighting poverty with microcredit: Experience in Bangladesh. Report, Oxford University Press, October, 1998

Khandker, S. R. (2005). Microfinance and poverty: Evidence using panel data from Bangladesh. The World Bank Economic Review, 19(2), 263-286. 


\section{MInstitute Macrothink $_{\text {Int }}$}

International Journal of Accounting and Financial Reporting ISSN 2162-3082

Malhotra, A. Schuler S.R. and Boender, Carol, (2002): Measuring Women's Empowerment as a Variable in International Development, Background Paper for World Bank Workshop on Poverty and Gender: New Perspectives.

Malhotra, A., \& Schuler, S. R. (2005).Women's empowerment as a variable in international development. In D. Narayan (Ed.), Measuring empowerment: Cross-disciplinary perspectives (pp. 71-88). Washington, DC: The Wirkd Bank.

Malhotra, A., Schuler, S. R., \&Boender, C.(2002). Measuring women's empowerment as a variable in international development, background paper prepared for the World Bank workshop on poverty and gender: New perspectives, June 28, 2002.

Mason, K.O. and Herbert L. Smith, (2003). Women's Empowerment and Social Context: Results from Five Asian Countries, The World Bank Washington D.C Rockefeller Foundation's Bellagio Study and Conference Center, 2 January 2003

Mayoux, L. (1997). The magic ingredient?Microfinace and women empowerment: Towards a Framework for Participatory Planning, Background Discussion Paper, ActionAid UK Washington, February 1997

Mersland, R., \&Strøm, R. Ø. (2010). Microfinance mission drift?. World Development, 38(1), 28-36. http://dx.doi.org/10.1016/j.worlddev. 2009.05.006.

Michael Pennock.(2006).The Gross National Happiness Abridged Survey, Population Health Epidemiologist, Vancouver Island HealthAuthority, Victoria, BC. Canada

Microfinance gateway, http://www.microflnancegateway.org/sec/fa

Ministry of Finance of the Government of Pakistan. (2013). Pakistan Economic Survey 2012-2013 Retrieved October 11, 2013, from

Montgomery, H., \& Weiss, J. (2011). Can commercially-oriented microfinance help meet the millennium development goals? Evidence from Pakistan. World Development, 39(1), 87-109. http://dx.doi.org/ 10.1016/j.worlddev.2010.09.001.

Morduch, J. (1999). The role of subsidies in microfinance: Evidence from the Grameen Bank. $\begin{array}{llll}\text { Journal of Development } & \text { Economics, 60(1), 248. }\end{array}$ http://dx.doi.org/10.1016/s0304-3878(99)00042-5.

Morvant-Roux, S., Gue'rin, I., Roesch, M., \&Moisseron, J.-Y. (2014). Adding value to randomization with qualitative analysis: The case of microcredit in rural morocco. World Development, 56, 302-312, http:// dx.doi.org/10.1016/j.worlddev.2013.03.002.

Mosedale, S. (2005). Assessing women's empowerment: Towards a conceptual framework. Journal of International Development, 17(2), 243-257. http://dx.doi.org/10.1002/jid.1212.

Muhammad, S. D., Shaheen, G., Naqvi, S. I. H., \&Zehra, S. (2012). Women empowerment and microfinance: A case study of Pakistan. African Journal of Business Management, 6(22), $6497-$ 


\section{Ml Macrothink}

International Journal of Accounting and Financial Reporting ISSN 2162-3082 2014, Vol. 4, No. 2

Niaz, U. (2003). Violence against women in South Asian countries.Archives of Women's Mental Health, 6(3), 173-184.http://dx.doi.org/ 10.1007/s00737-003-0171-9.

Niethammer, C., Saeed, T., Mohamed, S. S., \&Charafi, Y. (2007).Women entrepreneurs and access to finance in Pakistan. Women's Policy Journal of Harvard, 4, 1-12, Summer 2007.

Noponen, H. (2003). 12. The internal learning system - A tool for tracking and enhancing empowerment outcomes and wider social impacts of microfinance. IDS Bulletin, 34(4), $121-132$.

M. (1999).Bringing development back, into microfinance. Journal of Microfinance, 1(1), 8-19.

Pakistan Microfinance Network (2003) .Performance indicators Report, Pakistan Microfinance Network Secretariat, Islamabad.

Pakistan. (2009). Health of women in Pakistan Annual Report (pp. 8). Karachi, Pakistan: Society of Obstetricians \&Gynaecologists of Pakistan.

Parveen, S. (2007). Gender awareness of rural women in Bangladesh.

Parveen, S. and Ingrid- Ute Leohauser, (2004). Empowerment of rural women In Bangladesh: A Household Level Analysis, Conference On Rural Poverty Reduction Through Research And Transformation, DcutscherTropentag- Berlin- Germany.

Rahman, M. H., \&Naoroze, K. (2007). Women empowerment through participation in aquaculture: Experience of a large-scale technology demonstration project in Bangladesh, Journal of Social Science, volume,2, pp. 164-171.

Rahman, M.H. and KaziNaoroze (2007). Women Empowerment Through Participation In Aquaculture: Experience Of A Large Scale Technology Demonstration Project In Bagladesh, Journal Of Social Science 3(4) pp. 64-171

Rowlands, Jo. (1995). Questioning Empowerment. Working with women in Honduras. London: Oxfam United Kingdom

Sathar, Z. A., \&Kazi, S. (2000). Women's autonomy in the context of rural Pakistan. The Pakistan Development Review, 39(2), 89-110.

Schuler, S. R., \&Rottach, E. (2010).Women's empowerment across generations in Bangladesh. The Journal of Development Studies, 46(3), 379-396.Society of Obstetricians \&Gynaecologists

Skarlatos, k. (2004).Microfinance and Women.s Economic Empowerment. Bridging the Gap, Redesigning the Future..Working Paper No 1, Wisconsin Coordinating Council in Nicaragua.

Sukontamam, P. (2007). Micro-credit, fertility decisions, and women's empowerment in Bangladesh, working paper No 94, University of Adelaide.

Swain, R. B., \&Wallentin, F. Y. (2007). Does microfmance empower women? Evidence from Self Help Groups in India, working paper No.24,department of economics, Uppsala 


\section{Macrothink \\ International Journal of Accounting and Financial Reporting \\ ISSN 2162-3082 2014, Vol. 4, No. 2}

University, August 2007

Swain, R.B. (2007a). Can Microfinance Empower Women? Self Help Group in India, Department of Economics, UPPSALA University, ADAN.37

Swain, R.B. (2007b). Does Microfinance Empower Women? Evidence from Self Help Group in India, Working Paper No. 24, UPPSALA University, Department Of Economics.

The Millennium Development Goals Report. (2006).

Todaro, M.P. (2003). Economic Development. Eighth Edition, Addison Wesley Longman, Singapore.

Umashankar, D. (2006). Women's empowerment: Effect of participation in self-help groups.

UNDP Report. (2008).

UNDP. (1995). Human Development Report, New York: Oxford University Press.

wikipedia report. (2008).

World Health Organization (WHO).(1995). Presentation to the Fourth World.Conference on Women. Beijing, China.

ZubiaMumtazand Sarah Salway (2005), "I never go anywhere': extricating the links between women's mobility and uptake of reproductive health services in Pakistan", Social Science \& Medicine, Volume 60, Issue 8, April 2005, Pages 1751-1765. 